\title{
Probiotics for ruminants
}

\author{
CJ Newbold \\ Rowett Research Institute, Aberdeen, United Kingdom
}

Probiotics present an attractive alternative to the use of chemical and hormonal growth promoters in the livestock production industry. The preparations contain micro-organisms that have been used for many years in food production and thus are generally accepted as safe by both the farmer and the final consumer. The use of microorganisms to improve digestive and production efficiency in ruminants is not new. As early as 1954, Renz reported that the inclusion of $50 \mathrm{~g} / \mathrm{d}$ of an active yeast increased milk yield by $1.1 \mathrm{~kg} / \mathrm{d}$. Around the same time Beeson and Perry (1952) reported a $6 \%$ increase in the daily gain of steers fed $8 \mathrm{~g} / \mathrm{d}$ of active dried yeast. However, subsequent results were variable with studies reporting little or no increase in production (Renz and Koch, 1956 ; Lassiter et al, 1958). Recently there has been renewed interest in the use of low levels (10-100 g/day) of yeast and filamentous fungi in the diet of ruminants to improve productivity. Products based on Aspergillus oryzae and Saccharomyces cerevisiae are currently available commercially. Preparations based on other fungi have been described and products based on cultures other than $A$. oryzae and $S$. cerevisiae will no doubt become available in the future (Tapia et al, 1989; Campos et al, 1990; Theodorou et al, 1990; Mpofu and Ndlovu, 1994).

\section{Production responses}

Summarising published data, Fiems (1994) reported that on average the addition of $S$. cerevisiae to the diet lead to a $9.5 \%$ increase in live weight in calves, a $7.8 \%$ increase in live weight gain in growing adult cattle and a $3.9 \%$ response in milk yield in lactating cattle. Fiems (1994) noted that the increases in productivity were often associated with an increase in feed intake. However, production responses to all fungal probiotics have been variable, and in many cases fail to reach statistical significance (Newbold, 1995). While some of the variability in response to $S$. cerevisiae is undoubtedly due to differences in the effectiveness of different yeast preparations, there are indications that the diet and nutritional demands of the host may also be important. Harris and Lobo (1988) and Gunther (1990) found that the response to the inclusion of the yeast was greater in early as opposed to mid or late lactation. Williams et al (1991) observed larger responses in milk yield in response to $S$. cerevisiae addition as the ratio of concentrate to forage in the ration increased. Similarly, Spedding (1991) reported that $S$. cerevisiae stimulated weight gain in bulls fed a high cereal diet by almost $19 \%$ while the response in bulls fed a high forage diet was $6.7 \%$. Responses to yeast culture may also be modified by more subtle variations in the diet. Wallace and Newbold (1993) noted that responses in cattle fed corn silage tended to be higher than responses recorded in trials using diets based on grass silage. Quinonez et al (1988) found $S$. cerevisiae stimulated milk yield in cows fed a diet of alfalfa hay plus wheat but not when the wheat was replaced by corn. Adams et al (1995) noted that the response to $S$. cerevisiae in dairy cows was greater on a corn silage/alfalfa hay diet than on diets of either corn silage/bermuda grass hay or corn silage alone. Our understanding of the interaction between diet composition and the response of ruminants to yeast supplementation is incomplete. A better understanding of the mechanism by which $S$. cerevisiae is believed to drive production responses should allow the prediction of dietary situations in which production benefits might be expected.

\section{Effects of yeast culture in the rumen}

The effects of $S$. cerevisiae on animal productivity have been widely interpreted in terms of their action in the rumen (Offer, 1990; 
Wallace and Newbold, 1992; Dawson, 1993). Many changes have been reported in animals receiving $S$. cerevisiae, but an increase in the number of total culturable bacteria that can be recovered from the rumen would appear to be one of the most consistently reported responses, an effect which seems to be central to the action of the yeast (Figure 1) (Wallace and Newbold, 1992). While the increases in culturable bacteria in many studies might not reach statistical significance, studies in which yeast culture fails to stimulate bacterial numbers are rare (Dawson et al, 1990). What is not known, in most studies, is to what extent the increase in culturable bacteria recovered from the rumen reflects an actual increase in bacterial biomass as opposed to an increase in the viability of bacterial cells within the rumen. Kumar et al (1994) reported that S. cerevisiae increased both the viable and microscopic count of bacteria in the rumen of buffalo by $50 \%$, and although we failed to detect any increase in the microscopic count of bacterial cells from rumen fluid withdrawn from sheep fed $S$. cerevisiae we did note a $12 \%$ increase in acid precepitable protein, suggesting an increase in microbial protein (Newbold and McKain, unpublished observation). Increases in the flow of nitrogen from the rumen of animals fed $S$. cerevisiae have been reported (Williams et al, 1990). Carro et al (1992a) reported increases in the efficiency of synthesis of microbial protein in response to $S$. cerevisiae addition. In some studies this has been associated with an increased flow of microbial protein leaving the rumen and enhanced supply of amino acids entering the small intestine (Erasmus et al, 1992). However, Huhtanen (1991) and Carro et al (1992b), both studying the effects of $S$. cerevisiae in cattle fed grass silage based diets, failed to find any increase in the flow of microbial protein leaving the rumen. Olson et al (1994) found that although yeast stimulated microbial protein flow at the duodenum in grazing steers in June and July this effect disappeared later in the summer, suggesting that the effectiveness of $S$. cerevisiae diminished as the composition of the grazing changed during the season. An increase in microbial protein leaving the rumen may help explain the production benefits observed when yeast is added to the diet. However, it is evident that like the production responses themselves, increases in microbial protein synthesis in response to $S$. cerevisiae are dependent on the diet fed.

In addition to increases in total viable bacteria, increases in the cellulolytic bacterial population in response to $S$. cerevisiae have been reported (Wallace and Newbold, 1993). It has been suggested that an increase in the population of cellulolytic bacteria in the rumen could account for the increases in total tract digestibility of dry matter and acid detergent fibre which have been reported in animals fed S. cerevisiae (Wiedmeier et al, 1987). Increases in the rate but not the extent of ruminal fibre digestion have been noted in the rumen of animals fed $S$. cerevisiae (Erasmus et al, 1992; Kim et al, 1992). However, as with many of the ruminal effects mediated by fungal probiotics, other studies have found no effect (Mir and Mir, 1992), suggesting that the stimulation in digestion may also be modified by diet. Williams et al (1991) found $S$. cerevisiae stimulated the initial rate of hay degradation in the rumen of animals fed hay plus barley, but had no effect when concentrates were removed from the diet. $S$. cerevisiae appeared to increase rumen $\mathrm{pH}$

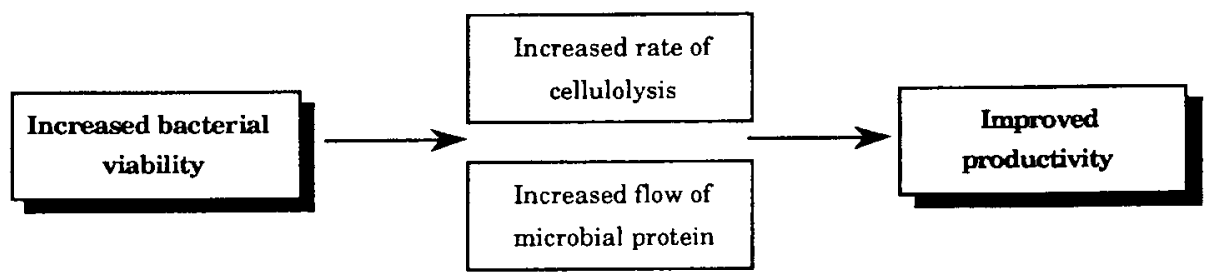

Figure 1. The central role of an increase in bacterial numbers in the rumen in driving production responses to $S$. cerevisiae addition. 
and it was suggested that the effects of $S$. cerevisiae on fibre digestion in the rumen might be mediated via an effect on rumen $\mathrm{pH}$. However, Chademana and Offer (1990) found $S$. cerevisiae stimulated dry matter degradation over a range of forage:concentrate ratios, with little effect on rumen $\mathrm{pH}$. Thus it appears that the stimulation of fibre degradation in the rumen by caused by $S$. cerevisiae can not be explained by a simple increase in rumen $\mathrm{pH}$.

While an increase in bacterial numbers, leading to an increase in microbial protein synthesis and ruminal fibre digestion, may help explain the effects of $S$. cerevisiae on ruminant productivity it remains unclear how small amounts of yeast in the diet can stimulate microbial numbers in the rumen. A number of mechanisms have been proposed (Rose, 1987; Wallace and Newbold, 1992), one of which, that the yeast removes oxygen from the rumen, is discussed below.

\section{Oxygen in the rumen}

Rose (1987) initially suggested that yeast might scavenge oxygen within the rumen thus stimulating the growth of anaerobic bacteria therein. Although the rumen is widely considered to be anaerobic, rumen gas contains between 0.5 and $1.0 \%$ oxygen (McArthur and Multimore, 1961). Hillman et al (1985) measured detectable levels of dissolved ruminal oxygen in situ shortly after feeding, oxygen declined below the levels of detection between 10 and $30 \mathrm{~min}$ after feeding but reappeared some $3 \mathrm{~h}$ later (Scott et al, 1983). Czerkawski (1969) calculated that oxygen transfer from saliva, food, and diffusion from the blood of the host animal might account for 38 I of oxygen entering the rumen of a sheep per day. We have measured rates of oxygen uptake by rumen fluid of between 60 and 100 $\mathrm{nmol} / \mathrm{min}$ per ml (Newbold et al, 1993). Assuming the rumen volume of a sheep to be $6 \mathrm{I}$, this equates to an oxygen-consuming capacity of between 11.5 and 16 I per day. Oxygen is toxic to anaerobic bacteria and it inhibits the growth of rumen bacteria in pure culture (Loesche, 1969; Marounek and Wallace, 1984) and the adhesion of cellulolytic rumen bacteria to cellulose (Roger et al, 1990). Yeast are well known for their high respiratory rate. Published values for oxygen uptake by $S$. cerevisiae (200 to $300 \mathrm{mmol} / \mathrm{min}$ per g)
(Bartford and Hall, 1979) suggest that they have respiratory rates several orders of magnitude greater than rumen fluid. Thus even at the low inclusions used in ruminant diets, yeast might be predicted to be beneficial to the rumen microflora.

I have measured the ability of different strains of $S$. cerevisiae to stimulate bacterial numbers in a rumen simulating fermentor and the ability of the yeast to stimulate oxygen uptake by rumen fluid. Traces of oxygen were introduced into strained rumen fluid incubated in vitro under argon and the effects on $\mathrm{O}_{2}$ concentration of adding different yeast preparations were measured. $S$. cerevisiae NCYC 240, NCYC 1026 and the commercial product, Yea-Sacc, increased the rate of oxygen disappearance by between 46 and $89 \%$. S. cerevisiae NCYC 694 and NCYC 1088 had no significant effect. As it had been shown previously that $S$. cerevisiae NCYC 240, NCYC 1026, and Yea-Sacc stimulated bacterial numbers in the rumen simulating fermentor, Rusitec, but S. cerevisiae NCYC 694 and NCYC 1088 did not (Newbold et al, 1995), it appeared that there is a relation between oxygen uptake and the ability of yeast to stimulate bacterial growth. Respirationdeficient (RD) mutants of $S$. cerevisiae NCYC 240 and NCYC 1026 were enriched by repeated culturing in the presence of ethidium bromide and were compared for their ability to stimulate rumen bacteria in Rusitec. $S$. cerevisiae NCYC 240 and NCYC 1026 stimulated the total and cellulolytic bacterial populations significantly, while $S$. cerevisiae NCYC 240 RD and NCYC 1026 RD did not (Table I).

In view of the apparent importance of oxygen as an inhibitory factor within the rumen the possibility of using micro-organisms other than $S$. cerevisiae to scavenge oxygen was investigated. The effect of Enterobacter aerogenes, a Gram negative enteric bacterium selected for its ability to stimulate oxygen uptake by rumen fluid, on rumen fermentation were compared with $S$. cerevisiae and dithioerythritol. Total bacterial numbers, in Rusitec, were stimulated by all three treatments (Table II). Cellulolytic bacterial numbers also tended to be higher (Table II).

Roger et al (1990) found that dithiothreitol (an epimer of dithioerythritol) stimulated the adhesion of $R$. flavefaciens to avicel. However, Jones and Pickard (1980) found that 
Table I. Effect of Saccharomyces cerevisiae NCYC 240, NCYC 1026 and respiration deficient (RD) mutants of these yeast on bacterial numbers in Rusitec.

\begin{tabular}{lccccc} 
& Control & NCYC 240 & NCYC 1026 & NCYC 240 RD & NCYC 1026 RD \\
\hline Total bacteria $\left(\times 10^{8} / \mathrm{ml}\right)$ & 2.8 & 5.1 & 3.9 & 2.7 & 2.8 \\
$\begin{array}{l}\text { Cellulolytic bacteria } \\
\left(\times 10^{6} / \mathrm{ml}\right)\end{array}$ & 3.5 & 37.3 & 87.3 & 5.3 & 4.5 \\
\end{tabular}

dithiothreitol inhibited the growth of several rumen bacteria including cellulolytic species. In the current experiment, while dithioerythritol apparently stimulated bacterial numbers, the reductions in dry matter degradation at $48 \mathrm{~h}$ and the daily output of volatile fatty acids suggested that prolonged exposure to dithioerythritol inhibited bacterial activity (Table II). As it was possible that the increase in bacterial numbers in vessels supplemented with $E$. aerogenes may simply have reflected recovery of $E$. aerogenes from Rusiter,, the effect of the bacterium on rumen fermentation was further investigated. Three sheep, fitted with rumen and duodenal cannulae, were supplemented with $2 \mathrm{~g} / \mathrm{d}$ of either $S$. cerevisiae or $E$. aerogenes. Both additives stimulated bacterial numbers in the rumen leading to a 25 and $27 \%$ increase in flow of microbial protein from the rumen with $S$. cerevisiae and $E$. aerogenes respectively (Figure 2 ).

The suggestion made by Rose (1987) that the probiotic activity of yeast is at least partially derived from its ability to remove potentially harmful oxygen from the rumen would appear to have been confirmed by experimental
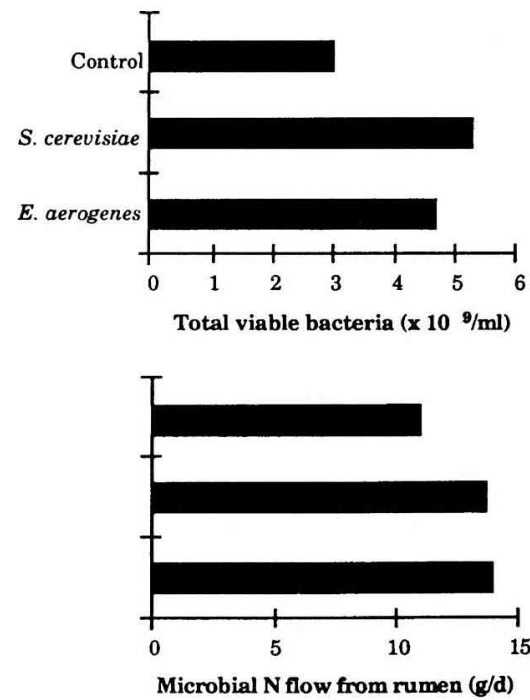

Figure 2. The effect of Saccharomyces cerevisiae NCYC 240 and Enterobacter aerogenes 10102 on viable bacterial numbers in the rumen and microbial $\mathrm{N}$ flow from the rumen of sheep.

Table II. Effect of Saccharomyces cerevisiae NCYC 240, Enterobacter aerogenes 10102 and dithioerythritol on the production of volatile fatty acids, microbial numbers and dry matter digestion in Rusitec.

\begin{tabular}{lcccc} 
& Control & S. cerevisiae & E. aerogenes & Dithioerythritol \\
\hline Acetate $(\mathrm{mmol} / \mathrm{d})$ & 19.6 & 18.7 & 23.0 & 16.7 \\
Propionate $(\mathrm{mmol} / \mathrm{d})$ & 8.6 & 8.1 & 9.2 & 7.7 \\
Butyrate $(\mathrm{mmol} / \mathrm{d})$ & 8.3 & 8.9 & 9.5 & 6.9 \\
Digestion of $\mathrm{DM}(\mathrm{g})$ & 9.38 & 8.54 & 8.50 & 7.61 \\
after $48 \mathrm{~h}$ incubation & & & & \\
Total bacteria $\left(\times 10^{8} / \mathrm{ml}\right)$ & 3.5 & 5.5 & 9.3 & 6.1 \\
Cellulolytic bacteria $\left(\mathrm{x} 10^{6} / \mathrm{ml}\right)$ & 2.6 & 8.5 & 5.6 & 6.3 \\
\hline
\end{tabular}


evidence. Interestingly, $A$. oryzae had no effect on oxygen uptake by rumen fluid. Further to the use of yeast to scavenge oxygen in the rumen, increases in rumen bacterial numbers were found in response to the inclusion of the chemical reducing agent dithioerythritiol and $E$. aerogenese, a microbe selected solely on its ability to increase oxygen consumption by rumen fluid in vitro. As noted above; production responses to the addition of yeast culture appear to be modified by the composition of the diet. Clearly responses to $S$. cerevisiae are likely to occur only in dietary and management situations where animals are likely to respond to increases in protein synthesis or fibre degradation. However, even at a ruminal level the responses to yeast appear to be dietdependent. Little is known about how diet effects dissolved oxygen concentrations in the rumen. However, a complex microbial ecosystem such as the rumen has many potential limiting factors, removal of one potential constraint (i.e. high concentrations of oxygen) will not stimulate growth if another is still limiting. Thus, El Hassan et al (1994) found that $S$. cerevisiae stimulated bacterial numbers in Rusitec when the diet was fresh frozen grass but not when silage prepared from the same forage was fed. It is known that diets containing a high proportion of grass silage support a low rate of microbial protein synthesis in the rumen (Agricultural Research Council, 1984). The reason for the low efficiency of synthesis is not entirely resolved, but in great part it must reflect the poor ATP yield obtained in the rumen from silage fermentation products (Thomas and Thomas, 1985). Under such circumstances it is unlikely that a reduction in dissolved oxygen due to the presence of $S$. cerevisiae will boost microbial growth. Indeed, more information is required to identify accurately dietary situations in which dissolved oxygen limits microbial protein synthesis in the rumen.

\section{Literature cited}

Agricultural Research Council (1984) The Nutrient Requirements of Ruminant Livestock, Suppl 1, Commonwealth Agricultural Bureaux, Slough.

Adams AL, Harris B, Van Horn HH, Wilcox CJ (1995) Effects of varying forage types on milk production responses to whole cottonseed, tallow, and yeast. J Dainy Sci 78, 573-581
Barford JP, Hall RJ (1979) An examination of the Crabtree effect in Saccharomyces cerevisiae: the role of respiratory adaptation. J Gen Microbiol $114,267-275$

Beeson WM, Perry TW (1952) Balancing the nutritional deficiencies of roughages for beef steers. J Anim Sci 11, 501-515.

Campos MR, Herrera-Saldana R, Viniegas CG, Diaz CM (1990) The effect of Aspergillus niger and Aspergillus oryzae (Amaferm) as probiotics on in situ digestibility of a high fibre diet. J Dairy Sci 73 (Suppl 1), 133

Carro MD, Lebzien P, Rohr K (1992a) Influence of yeast culture on the in vitro fermentation (Rusitec) of diets containing variable portions of concentrates. Anim Feed Sci Technol 37, 209-220

Carro MD, Lebzien P, Rohr K (1992b) Effects of yeast culture on rumen fermentation, digestibility and duodenal flow in dairy cows fed a silage based diet. Livestock Prod Sci 32, 219-229

Chademana I, Offer NW (1990) The effect of dietary inclusion of yeast culture on digestion in the sheep. Anim Prod 50, 483-489

Czerkawski JW (1969) Methane production in ruminants and its significance. World Rev Nutr Diet 11, 240-282

Dawson KA, Newman KE, Boling JA (1990) Effects of microbial supplements containing yeast and lactobacilli on roughage-fed ruminal microbial activities. J Anim Sci 68, 3392-3398

Dawson KA (1993) Current and future role of yeast culture in animal production: A review of research over the last six years. In: Biotechnology in the Feed Industry (Lyons TP, ed) Altech Technical Publications, Nicholasville, Kentucky, 269-291

El Hassan SM, Newbold CJ, Wallace RJ (1994) The effect of yeast culture addition to diets of grass and grass silage on rumen bacterial numbers. Anim Prod 58, 451

Erasmus LJ, Botha PM, Kistner A (1992) Effect of yeast culture supplementation on production, rumen fermentation, and duodenal nitrogen flow in dairy cows. J Dairy Sci 75, 3056-3065

Fiems LO (1994) The use of yeast in practical diets for ruminants. In: Microorganisms and enzyme preparations in animal nutrition (Castanon JIR, ed) Directorate-General for Agriculture, European Commission, Brussels, 159-173

Gunther KD (1990) Yeast Culture: Success under German dairy conditions. The Feed Compounder, January

Harris B, Lobo R (1988) Feeding yeast culture to lactating dairy cows. J Dairy Sci 77 (Suppl 1), 276

Hillman K, Lloyd D, Williams AG (1985) Use of a portable quadrupole mass spectrometer for the measurement of dissolved gas concentrations in ovine rumen liquor in situ. Curr Microbiol 12, 335-340 
Huhtanen $P$ (1991) Effects of yeast culture supplement on digestion of nutrients and rumen fermentation in cattle fed on a grass silage barley diet. J Agric Sci Finland 64, 443-453

Jones GA, Pickard MD (1980) Effect of titanium (III) citrate as a reducing agent on growth of rumen bacteria. App/ Environ Microbio/ 39, 1144-1147

Kim DY, Wandersee MK, Batallas CE, Dawson BA, Kent MR, Figueroa MR, Arambel MJ, Walters JL (1992) Effect of feeding yeast culture with or without Aspergillus oryzae on dry matter disappearance in three different forage types. $J$ Dairy Sci 75 (Suppl 1), 206

Kumar U, Sareen VK, Singh S (1994) Effect of Saccharomyces cerevisiae yeast culture supplement on ruminal metabolism in buffalo calves given a high concentrate diet. Anim Prod 59, 209-215

Lassiter CA, Huffman CF, Duncan CW (1958) Effect of a live yeast culture and trimethylalkylammonium stearate on performance of milking cows. J Dairy Sci 41, 1077-1090

Loesche WJ (1969) Oxygen sensitivity of various anaerobic bacteria. Appl Microbiol 18, 723-727

Marounek M, Wallace RJ (1984) Influence of culture $E_{h}$ on the growth and metabolism of the rumen bacteria Selenomonas ruminantium, Bacteroides amylophilus, Bacteroides succinogenes and Streptococcus bovis in batch culture. $J$ Gen Microbiol 130, 223-229

McArthur JM, Multimore JE (1961) Rumen gas analysis by gas solid chromatography. Can $J$ Anim Sci 41, 187- 192

Mir YS, Mir Z (1992) Effect of addition of live-yeast culture (Saccharomyces cerevisiae) on feed digestibility, degradability in the rumen and performance of steers. J Anim Sci 70 (Suppl 1), 309

Mpofu IDT, Ndlovu LR (1994) The potential of yeast and natural fungi for enhancing fibre digestibility of forages and roughages. Anim Feed Sci Tech $48,39-47$

Newbold CJ (1994) Fungi and probiotics in ruminant nutrition. In: Microorganisms and enzyme preparations in animal nutrition (Castanon JIR, ed) Directorate-General for Agriculture, European Commission, Brussels, 177-191

Newbold CJ (1995) Microbial feed additives for ruminants. In: Biotechnology in Animal Feeds and Animal feeding (Chesson A, Wallace RJ, eds) (in press)

Newbold CJ, Wallace RJ, Mclntosh FM (1993) The stimulation of rumen bacteria by Saccharomyces cerevisiae is dependent on the respiratory activity of the yeast. J Anim Sci 71 (Suppl 1), 280.

Newbold CJ, Wallace RJ, Chen XB, Mclntosh FM (1995) Different strains of Saccharomyces cerevisiae differ in their effects on rumen fermentation both in vitro and in sheep. $J$ Anim Sci 73, 1811-1818

Offer NW (1990) Maximising fiber digestion in the rumen: The role of yeast culture. In: Biotechnology in the Feed Industry (Lyons TP, ed) Altech Technical Publications, Nicholasville, Kentucky, 79-93

Olson KC, Caton JS, Kirby DR, Norton PL (1994) Influence of yeast culture supplementation and advancing season on steers grazing mixed grass prairie in the northern plains: II Ruminal fermentation, site of digestion, and microbial efficiency. J Anim Sci 72, 2158-2170

Quinonez JA, Bush LA, Nalsen T, Adams GD (1988) Effect of yeast culture on intake and production of dairy cows fed high wheat rations. J Dairy Sci 71 (Suppl 1), 275

Renz F (1954) Milk production with the active yeast concentrate "Astrol". Zuchtungskunde 26, 228-234

Renz F, Koch A (1956) Milk production with the active yeast concentrate "Astrol". Zuchtungskunde 28, 298-304

Roger V, Fonty G, Komisarczuk-Bony S, Gouet Ph (1990) Effects of physiochemical factors on the adhesion to cellulose Avicel of the ruminal bacteria Ruminicoccus flavefaciens and Fibrobacter succinogenes subsp. succinogenes. Appl Environ Microbiol 56, 3081-3087

Rose AH (1987) Yeast Culture, A microorganism for all species: A theoretical look at its mode of action. In: Biotechnology in the Feed Industry (Lyons TP, ed) Altech Technical Publications, Nicholasville, Kentucky, 113-118

Scott RI, Yarlett N, Hillman K, Williams TN, Williams AG, Lloyd D (1983) The presence of oxygen in rumen liquor and its effects on methanogenesis. $J$ App/ Bacteriol 55, 43-149

Spedding A (1991) Effects of Yea-sacc1026 on Performance of Beef Bulls fed Cereal or Silage Beef Diets Containing Monensin. In: Biotechnology in the Feed Industry (Lyons TP, ed) Alltech Technical Publications, Nicholasville, Kentucky, 333-336

Tapia MN, Herrera-Saldana R, Mex S, Russos S, Viniegra G, Gutierrez M (1989) The effect of four fungal compounds as probiotics on in vitro dry matter disappearance of different feedstuffs. $J$ Anim Sci 67 (Suppl 1), 521

Theodorou MK, Beever DE, Haines MJ, Brooks A (1990) The effect of a fungal probiotic on intake and performance of early weaned calves. Anim Prod 53, 577

Thomas C, Thomas PC (1985) Factors Affecting The Nutritive Value of Grass Silages. In: Recent Advances in Animal Nutrition (Haresign W, Cole DJA, eds) Butterworths, London, 223-256 
Wallace RJ, Newbold CJ (1992) Probiotics for Ruminants. In: Probiotics: The Scientific Basis (Fuller $\mathrm{R}$, ed) Chapman and Hall, London, 317353

Wallace RJ, Newbold CJ (1993) Rumen Fermentation and its manipulation: The development of yeast cultures as feed additives. In : Biotechnology in the Feed Industry (Lyons TP, ed) Alltech Technical Publications, Kentucky, 173-192

Wiedmeier RD, Arambel MJ, Walters JL (1987) Effect of yeast culture and Aspergillus oryzae fermentation extract on ruminal characteristics and nutrient digestibility. J Dairy Sci 70, 2063-2068

Williams PEV, Walker A, MacRae JC (1990) Rumen probiosis: The effects of addition of yeast culture (viable yeast (Saccharomyces cerevisiae) plus growth medium) on duodenal protein flow in wether sheep. Proc Nutr Soc 49, 128A

Williams PEV, Tait CAG, Innes GM, Newbold CJ (1991) Effects of the inclusion of yeast culture (Saccharomyces cerevisiae plus growth medium) in the diet of dairy cows on milk yield and forage degradation and fermentation patterns in the rumen of sheep and steers. J Anim Sci69, 3016- 3026 